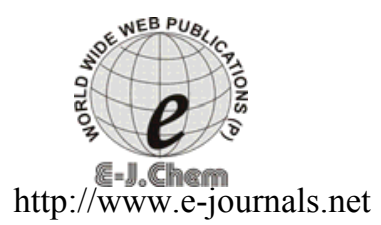

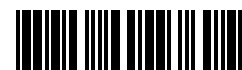

ISSN: 0973-4945; CODEN ECJHAO

E-Journal of Chemistry

http://www.e-journals.net

2011, 8(S1), S309-S317

\title{
DNA Binding and Cleavage Activity of Binuclear Metal Complexes with Benzil- $\alpha$-Monoxime Thiosemicarbzone
}

\author{
M. S.SURENDRA BABU ${ }^{\S *}$, T.B.PATRUDU ${ }^{\S}$ and K.HUSSAIN REDDY \\ ${ }^{\S}$ Department of Chemistry \\ Gitam University, Hyderabad - 502 329, India \\ Department of Chemistry \\ Sri Krishnadevaraya University, Anantapur 515 002, India \\ manabolu@gmail.com
}

Received 16 December 2010; Accepted 28 February 2011

\begin{abstract}
Transition metal complexes of copper(II), nickel(II), cobalt(II) and iron(II) with benzil- $\alpha$-monoxime thiosemicarbazone (BMOT) have been synthesized and characterized by molar conductance, magnetic moments, IR, electronic and ESR spectroscopy. Electrochemical behaviors of these complexes were investigated by cyclic voltammetric studies. The nuclease activity of these complexes has been investigated on double-stranded pBR322 circular plasmid DNA by using the gel electrophoresis experiments in presence and absence of oxidant $\left(\mathrm{H}_{2} \mathrm{O}_{2}\right)$. In the absence of oxidant DNA cleavage by hydrolytically was observed a less discernable, whereas in presence of oxidant $\left(\mathrm{H}_{2} \mathrm{O}_{2}\right)$ all complexes showed increased nuclease activity.
\end{abstract}

Keywords: Benzil- $\alpha$-monoxime thiosemicarbazone, Transition metal complexes, Cyclic voltammetry, DNA cleavage, Oxidative cleavage

\section{Introduction}

Thiosemicarbazones and oximes are widely studied in organic synthesis, metal ion complexation ${ }^{1-4}$. These ligands have good complexing ability and their activity increases on complexation with transition metal ions. Thiosemicarbazones are broadly employed ligands containing sulphur-nitrogen for therapeutic ${ }^{5}$, anti malarial, anti viral and anti microbial activity $^{6-8}$. The toxicological importance of the $-\mathrm{N}-\mathrm{C}=\mathrm{S}$ moiety has been well established in antifungal, antibacterial and pesticides ${ }^{9,10}$. Coordination of thiosemicarbazone and oxime ligands with transition metal often enhances their biological activity ${ }^{11-13}$. Interaction of transition metal complexes with nucleic acids are of paramount importance for the designing 
of chemotherapeutic drugs, regulating gene expression and designing tools for molecular biology ${ }^{14-16}$. Plenty of studies came up with that DNA is the major intracellular target of antitumor drugs because of the interaction between small molecules and these compounds can cause DNA damage in cancer cells, preventing the division of cancer cells and ending in cell death ${ }^{17,18}$. Although transition metal complexes of oximes ${ }^{19}$ and thiosemicarbazones ${ }^{20}$ have been extensively studied, much remains to be investigated on the ligational behavior of compounds containing both oxime and thiosemicarbazone functional groups. Survey of literature revealed that among ligands containing both oxime and thiosemicarbazone are less targeted for DNA interaction and cleavage activity. In the light of the above we report synthesis and characterization of benzil- $\alpha$-monoxime thiosemicarbazone and its $\mathrm{Cu}(\mathrm{II})$, $\mathrm{Ni}(\mathrm{II}), \mathrm{Co}(\mathrm{II})$ and $\mathrm{Fe}(\mathrm{II})$ complexes and their DNA binding and cleavage activities against plasmid pBR322 DNA.

\section{Experimental}

All chemicals were of analytical grade obtained from Merck and were used without further purification. Agarose used in gel electrophoresis was purchased from Sigma, CT DNA and plasmid pBR322 were purchased from Genie Biolabs (Bangalore, India).

The elemental analyses were performed using a Perkin-Elmer 2400CHNS elemental analyzer. Molecular weights of the complexes were determined by cryoscopic method using camphor as solvent. Magnetic moments were determined in polycrystalline state on a PAR model-155 vibrating sample magnetometer operating at field strength of 2-8 kG. High purity Ni metal (Saturation moment $55 \mathrm{emu} / \mathrm{g}$ ) was used as standard. The molar conductance of the complexes in dimethylformamide (DMF) $(1073 \mathrm{M})$ solution was measured at $(28+2){ }^{\circ} \mathrm{C}$ with a systronic model 303 direct-reading conductivity bridge. The electronic spectra were recorded in DMF with a Schimadzu UV-160A spectrophotometer. FTIR spectra were recorded in the range $4000-50 \mathrm{~cm}^{-1}$ with a Brucker IFS $66 \mathrm{~V}$ in $\mathrm{KBr}$ and polyethylene medium. ESR spectra were recorded on Varian E-122 X-band spectrophotometers at liquid nitrogen temperature (LNT) in DMF. The voltammetric measurements were performed on Bio-Analytical Instrument, BAS$\mathrm{CV}-27$ assembly in conjunction with an X-Y recorder. Measurements were made on the degassed (N2 bubbling for $5 \mathrm{~min}$ ) complex solution in DMF (1073 M) containing $0.1 \mathrm{M}$ tetraethyl-ammoniumperchlorate as the supporting electrolyte. A three-electrode system consisting of glassy carbon (working) platinum (auxiliary) and $\mathrm{Ag} / \mathrm{AgCl}$ (reference) electrodes was used.

\section{Assay of nuclease activity}

The DMF solution containing metal complexes was taken in a clean Eppendorf tube and 3.3 $\mathrm{ml}$ of plasmid DNA was added. The contents were incubated for $2 \mathrm{~h}$ at $37^{\circ} \mathrm{C}$ and loaded on $0.8 \%$ agarose gel after mixing $5 \mu \mathrm{L}$ of loading buffer $(0.25 \%$ bromophenol blue $+25 \%$ xylene cyanol $+30 \%$ glycerol). Electrophoresis was performed at constant voltage $(80 \mathrm{~V})$ till bromophenol blue reached $3 / 4^{\text {th }}$ of the gel. Further the gel was stained for 10 min by immersing it in ethidium bromide solution $\left(5 \mathrm{mg} / \mathrm{mL}\right.$ of $\left.\mathrm{H}_{2} \mathrm{O}\right)$. The gel was then de-stained for $10 \mathrm{~min}$ by keeping it in sterile distilled water and plasmid bands were visualized by viewing the gel under transilluminator and then photographed.

\section{DNA Binding studies}

All measurements with CT DNA were performed in buffer Tris- $\mathrm{HCl} 5 \mathrm{mM}$ (pH 7.2), $50 \mathrm{mM}$ $\mathrm{NaCl}$ solution. The UV absorbance ratio $\lambda_{260} / \lambda_{280}$ was $1.8-1.9$, indicating the DNA was sufficiently 
free of protein. The concentration of CT DNA per nucleotide was determined from the absorption intensity at $260 \mathrm{~nm}$ with the known $\varepsilon$ value of $6600 \mathrm{M}^{-1} \mathrm{~cm}^{-1}$. The absorption titrations were performed by adding increasing amounts of CT DNA to a solution of the complex at a fixed concentration contained in a quartz cell and recording the UV-Vis spectrum after each addition. The absorption of CT DNA was subtracted by adding the same amounts of DNA to a blank. The data were then fitted to Eq. (1) to obtain the intrinsic binding constant, $\mathrm{K}_{\mathrm{b}}{ }^{21}$.

$$
[\mathrm{DNA}] /\left(\varepsilon_{\mathrm{a}}-\varepsilon_{\mathrm{f}}\right)=[\mathrm{DNA}] /\left(\varepsilon_{\mathrm{b}}-\varepsilon_{\mathrm{f}}\right)+1 / \mathrm{K}_{\mathrm{b}}\left(\varepsilon_{\mathrm{b}}-\varepsilon_{\mathrm{f}}\right)
$$

Where $\varepsilon_{\mathrm{a}}, \varepsilon_{\mathrm{f}}$ and $\varepsilon_{\mathrm{b}}$ are the apparent, free and bound metal complex extinction coefficients, respectively. A plot of [DNA] / $\left(\varepsilon_{\mathrm{a}}-\varepsilon_{\mathrm{f}}\right) V s$ [DNA] gave a slope of $1 /\left(\varepsilon_{\mathrm{b}}-\varepsilon_{\mathrm{f}}\right)$ and a $y$-intercept equal to $1 / \mathrm{K}_{\mathrm{b}}\left(\varepsilon_{\mathrm{b}}-\varepsilon_{\mathrm{f}}\right)$. Thus, $\mathrm{K}_{\mathrm{b}}$ is the ratio of the slope to the $y$-intercept.

\section{Synthesis of benzil- $\alpha$-monoxime thiosemi-carbazone (BMOT)}

Benzil- $\alpha$-monoxime was prepared by following the literature procedure ${ }^{21}$. Benzil- $\alpha$ monoxime $(0.025 \mathrm{~mol})$ and thiosemicarbazide $(0.025 \mathrm{~mol})$ are taken in 1:1 ration, add $500 \mathrm{~mL}$ of $1 \% \mathrm{HCl}$-ethanol in clean round bottom flask and refluxed for $10 \mathrm{~h}$. The reaction mixture is cooled and left over night, yellow coloured product was formed, collected by filtration, washed several times with hot water, small quantities of cold methanol and hexane and dried in vacuo. Yield $86 \%$, m.p. $158-160{ }^{\circ} \mathrm{C}$; I.R.:- 3372(m), $v(\mathrm{OH})$ of oxime group, 3338(m), 3283(m), $v(\mathrm{NH})$, symmetric stretch of $\mathrm{NH}_{2} ; 1631(\mathrm{~s}), v(\mathrm{C}=\mathrm{N})$ Schiff base/oxime; 1262(w), $v(\mathrm{C}=\mathrm{S}) ; 1118(\mathrm{~m}), v(\mathrm{C}-\mathrm{N})$. NMR :- DMSO-d 6.7 .36 - 7.93 (multiplet, 10H, phenyl protons); $8.45-8.82$ (multiplet, $2 \mathrm{H}$, amino protons), 11.79 (singlet, $1 \mathrm{H}$, hydrazino proton) and 12.49 (singlet, $1 \mathrm{H},=\mathrm{N}-\mathrm{OH}$ proton). $\mathrm{MS} \mathrm{m} / \mathrm{z}(\%): 299(\mathrm{M}+1) ; 298\left(\mathrm{M}^{+}\right)$peaks.

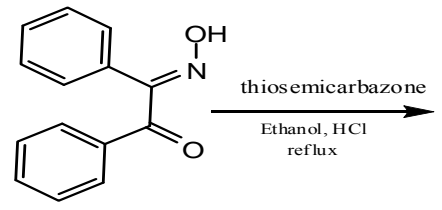

Scheme 1. Synthesis of BMOT ligand<smiles>NC(=S)NN=C(c1ccccc1)c1ccccc1</smiles>

$\mathrm{NH}_{2}$

\section{Synthesis of metal complexes}

The metal complexes were prepared by mixing hot aqueous ethanolic solution of metal chlorides (expect iron(II) complexes, an aqueous solution of ferrous ammonium sulphate was used) and BMOT in the molar ratio of $1: 1$. The reaction mixture is heated under reflux for $3 \mathrm{~h}$. The reaction mixture was then cooled and left overnight in refrigerator. Crystalline complexes which separated out were collected by filtration. The solid complexes are washed with hot distilled water and small quantity of cold methanol.

\section{Results and Discussion}

BMOT ligand containing two functional groups viz., oxime and thiosemicarbazone, their metal complexes are stable at room temperature and non-hygroscopic in nature. All complexes are freely soluble in dimethylformamide (DMF), dimethyl sulphoxide (DMSO), partially soluble in alcohol and insoluble in water. Physical properties and molecular weight calculated by cryoscopic method are given in Table 1 . The molar conductance values of these complexes measured in DMF solution (Table 2) suggest an electrolytic nature for these metal complexes. The magnetic moment values are found to be between 1.3 to 3.5 B.M ranges, which indicate the presence of unpaired electrons. Data reveal that all complexes 
have low magnetic moment values, than the expected values which may be attributed to the presence of magnetically coupled metal centers in dimeric complexes. This is further supported by molecular weight calculated by cryoscopic method suggesting the presence of complex to metal ratio in 1:1.

Table 1. Physical, molar and magnetic properties of BMOT complexes

\begin{tabular}{|c|c|c|c|c|c|c|c|}
\hline $\begin{array}{l}\text { Name of the } \\
\text { complex }\end{array}$ & Colour & $\frac{\partial}{00}$ & $\begin{array}{l}\text { Melting } \\
\text { point, }{ }^{\circ} \mathrm{C}\end{array}$ & 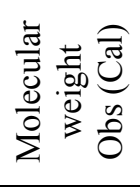 & 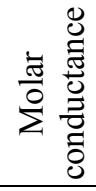 & 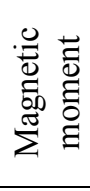 & $\begin{array}{l}\text { Magnetic } \\
\text { values }\end{array}$ \\
\hline$[\mathrm{Cu}(\mathrm{BMOT})]_{2} \mathrm{Cl}_{2}$ & $\begin{array}{l}\text { Dark } \\
\text { green }\end{array}$ & 60 & $235-237$ & $\begin{array}{l}720 \pm 10 \\
(729)\end{array}$ & 73.0 & 1.30 & 1.7 H.S/L.S \\
\hline$[\mathrm{Ni}(\mathrm{BMOT})]_{2} \mathrm{Cl}_{2}$ & Green & 45 & $241-243$ & $\begin{array}{c}692 \pm 10 \\
(704)\end{array}$ & 59.6 & 1.54 & 2.8 H.S/L.S \\
\hline $\begin{array}{c}{[\mathrm{Co}(\mathrm{BMOT})} \\
\left.\left(\mathrm{H}_{2} \mathrm{O}\right)_{2}\right]_{2} \mathrm{Cl}_{2}\end{array}$ & Black & 70 & $232-240^{*}$ & $\begin{array}{c}770 \pm 10 \\
(782)\end{array}$ & 59.6 & 1.83 & $\begin{array}{l}3.9 \text { H.S / } \\
1.7 \text { L.S }\end{array}$ \\
\hline $\begin{array}{l}{[\mathrm{Fe}(\mathrm{BMOT})} \\
\left.\left(\mathrm{H}_{2} \mathrm{O}\right)_{2}\right]_{2} \mathrm{SO}_{4} \\
\end{array}$ & $\begin{array}{c}\text { Reddish } \\
\text { brown }\end{array}$ & 60 & $220-225$ & $\begin{array}{c}794 \pm 10 \\
(810) \\
\end{array}$ & 23.00 & 2.02 & 4.9 H.S / L.S \\
\hline
\end{tabular}

${ }^{\circ}$ Decomposed in the range indicated

Table 2. Electronic spectral data, $\mathrm{cm}^{-1}$

\begin{tabular}{ccc}
\hline Complexes & d-d & Charge transfer \\
\hline$[\mathrm{Cu}(\mathrm{BMOT})]_{2} \mathrm{Cl}_{2}$ & 24691 & 38461 \\
{$[\mathrm{Ni}(\mathrm{BMOT})]_{2} \mathrm{Cl}_{2}$} & 17543 & 37878 \\
{$\left[\mathrm{Co}(\mathrm{BMOT})\left(\mathrm{H}_{2} \mathrm{O}\right)_{2}\right]_{2} \mathrm{Cl}_{2}$} & 16666,14705 & 38461,33898 \\
{$\left[\mathrm{Fe}(\mathrm{BMOT})\left(\mathrm{H}_{2} \mathrm{O}\right)_{2}\right]_{2} \mathrm{SO}_{4}$} & 19890 & 37735 \\
\hline
\end{tabular}

\section{Electronic spectra}

The electronic spectra were recorded in chloroform and DMF solvents. The electronic spectral data of metal complexes are given in Table 3. The spectral data of copper complexes are dominated by intense intra-ligand and charge transfer (CT) bands. The presence of a single $\mathrm{d}-\mathrm{d}$ band may be attributed to the symmetric nature of ligand field. Charge transfer band in the spectrum of copper complex of BMOT is observed at 38461. The electronic spectra of nickel complex exhibit medium intensity bands at 17543 suggesting a square planar geometry for the complex. A charge transfer band at 37878 is also observed.

Table 3. Selective I.R. bands, $\mathrm{cm}^{-1}$ with tentative assignments

\begin{tabular}{lccccccc}
\hline \multicolumn{1}{c}{ Complex } & $v(\mathrm{~N}-\mathrm{H})$ & $v(\mathrm{Ar}-\mathrm{H})$ & $v(\mathrm{C}=\mathrm{N})$ & $v(\mathrm{C}=\mathrm{S})$ & $v(\mathrm{M}-\mathrm{N})$ & $v(\mathrm{M}-\mathrm{S})$ & $v(\mathrm{M}-\mathrm{O})$ \\
\hline BMOT & 3176 & 3065 & 1645 & 1190 & - & - & - \\
{$[\mathrm{Cu}(\mathrm{BMOT})]_{2} \mathrm{Cl}_{2}$} & 3128 & 3020 & 1625 & 1179 & 480 & 365 & 534 \\
{$[\mathrm{Ni}(\mathrm{BMOT})]_{2} \mathrm{Cl}_{2}$} & 3125 & 3040 & 1632 & 1180 & 479 & 360 & 546 \\
{$\left[\mathrm{Co}(\mathrm{BMOT})\left(\mathrm{H}_{2} \mathrm{O}\right)_{2}\right]_{2} \mathrm{Cl}_{2}$} & 3098 & 3007 & 1617 & 1175 & 488 & 366 & 548 \\
{$\left[\mathrm{Fe}(\mathrm{BMOT})\left(\mathrm{H}_{2} \mathrm{O}\right)_{2}\right]_{2} \mathrm{SO}_{4}$} & 3104 & 3042 & 1623 & 1115 & 465 & 362 & 538 \\
\hline
\end{tabular}

The electronic spectra of cobalt complexes recorded in DMF show two distinct bands at 16666, $14705 \mathrm{~cm}^{-1}$, attributed to the ${ }^{4} \mathrm{~T}_{1 \mathrm{~g}}(\mathrm{~F}) \rightarrow{ }^{4} \mathrm{~A}_{2 \mathrm{~g}}(\mathrm{~F})\left(\mathrm{v}_{2}\right)$ and ${ }^{4} \mathrm{~T}_{1 \mathrm{~g}}(\mathrm{~F}) \rightarrow{ }^{4} \mathrm{~A}_{1 \mathrm{~g}}(\mathrm{~F})\left(\mathrm{v}_{3}\right)$ transitions respectively in an octahedral field. Important ligand field parameters are respectively summarized for cobalt complexes of DAMOT, PPDOT and BMOT. B (Racah parameter) 
720; $10 \mathrm{Dq}, 7848$; and $\beta_{35} ; 0.72$. The calculated values lie in the same range as expected for an octahedral Co(II) complex. The ratio of $v_{2}$ observed to $v_{1}$ calculated is found to be 2.73 as required for octahedral cobalt(II) complex.

Iron(II) complexes exhibit an intense charge transfer band at $37735 \mathrm{~cm}^{-1}$ assigned to $\mathrm{T}_{2 \mathrm{~g}}(\mathrm{Fe}) \rightarrow \pi^{*}(\mathrm{~L})$ transition. The band observed at $19890 \mathrm{~cm}^{-1}$ (BMOT) in the electronic spectrum of iron(II) complexes is assigned to ${ }^{5} \mathrm{~T}_{2 \mathrm{~g}} \rightarrow{ }^{5} \mathrm{~B}_{1 \mathrm{~g}}$; which is generally observed in 6-coordinte iron(II) complexes. In electronic spectra of metal complexes recorded in either chloroform (or) DMF solvent, there is no appreciable shift in d-d transition suggesting that there is no coordination of DMF solvent.

\section{IR spectral data}

The important vibrational bands of metal complexes are given in Table 4. In principle, the ligand can exhibit thione-thiol tautomerism, since it contains a thioamide $-\mathrm{NH}-\mathrm{C}=\mathrm{S}$ functional group ${ }^{22}$. The absence of SH band at $2570 \mathrm{~cm}^{-1}$ and presence of NH band at $3200 \mathrm{~cm}^{-1}$ region in the IR spectrum of BMOT suggest that the ligand remains in thione forms at least in solid state.

A strong band appearing at $1185 \mathrm{~cm}^{-1}$ in the spectrum of BMOT is shifted to lower frequency $1180-1115 \mathrm{~cm}^{-1}$ in metal complexes indicating the involvement of thio-keto sulphur in coordination. A strong band observed around $3400 \mathrm{~cm}^{-1}$ range in the IR spectrum of BMOT is disappeared in the spectra of all complexes suggesting deprotonation of oxime $\mathrm{OH}$ in complex formation. The $>\mathrm{C}=\mathrm{N}$ - (imine band) is observed at $1603 \mathrm{~cm}^{-1}$ in the IR spectrum of BMOT is shifted to lower wave numbers in the spectra of complexes suggesting the participation of imine nitrogen atom in coordination. Broad and strong bands in the IR spectra of $\mathrm{Co}(\mathrm{II})$ and $\mathrm{Fe}(\mathrm{II})$ complexes in $3400-3500 \mathrm{~cm}^{-1}$ region suggest the presence of coordinated water molecules. The appearance of bands $800-825 \mathrm{~cm}^{-1}$ region are assigned to wagging modes of water molecules in iron(II) and cobalt(II) complexes. Additional bands are observed in Far IR spectra of metal complexes in $500-430$ and $360-300 \mathrm{~cm}^{-1}$ regions due to $v(\mathrm{M}-\mathrm{N})$ and $v(\mathrm{M}-\mathrm{S})$ modes respectively.

Table 4. Spin Hamiltonian and orbital reduction parameters of $\mathrm{Cu}(\mathrm{II})$ complexes

\begin{tabular}{ccccccccc}
\hline Parameters & $\mathrm{g}_{\|}$ & $\mathrm{g}_{\perp}$ & $\mathrm{g}_{\mathrm{av}}$ & $\mathrm{G}$ & $\mathrm{A}_{\|}{ }^{*}$ & $\mathrm{~A}_{\perp}{ }^{*}$ & $\mathrm{~A}_{\mathrm{av}}{ }^{*}$ & $\mathrm{~K}_{\|}$ \\
\hline $\mathrm{Cu}(\mathrm{BMOT})$ & 2.3322 & 2.0589 & 2.1956 & 5.8286 & 0.01581 & 0.00139 & 0.06619 & 0.9110 \\
\hline \multicolumn{8}{c}{ Units in $\mathrm{cm}^{-1}$} &
\end{tabular}

\section{ESR spectra}

ESR spectra of copper complexes of BMOT are recorded in DMF at liquid nitrogen temperature. ESR spectra of copper complex are given in Figure 1. The spectra exhibit a set of four well-resolved peaks in the low field region and weakly resolved signals in high field region corresponding to $\mathrm{g}_{\|}$and $\mathrm{g}_{\perp}$ respectively. The spin-Hamiltonian, orbital reduction and bonding parameters of these complexes are given in Table 5. The $\mathrm{g}_{\|}$and $\mathrm{g}_{\perp}$ values are computed from the spectra using tetracyanoethylene (TCNE) free radical as $g$ marker.

The ' $\mathrm{g}$ ' tensor values of a $\mathrm{Cu}(\mathrm{II})$ complexes can be used to derive the ground state. In square-planar complexes the unpaired electron lies in the $\mathrm{dx}^{2}-\mathrm{y}^{2}$ orbital giving ${ }^{2} \mathrm{~B}_{1 \mathrm{~g}}$ as the ground state with $\mathrm{g}_{\|}>\mathrm{g}_{\perp}>2.00$ while the unpaired electron lies in the $\mathrm{dz}^{2}$ orbital giving ${ }^{2} \mathrm{~A}_{1 \mathrm{~g}}$ as the ground state with $g_{\perp}>g_{\|}>2.00$. From observed values it is clear that $g_{\|}>g_{\perp}>2.00$ which suggest the fact that the unpaired electrons lies predominately in the $\mathrm{dx}^{2}-\mathrm{y}^{2}$ orbital ${ }^{23}$. The $g_{a v}$ value for these complexes are greater than 2 indicating covalent property ${ }^{24}$. 
For in-plane $\pi$-bonding $\mathrm{K}_{\|}<\mathrm{K}_{\perp}$, while for out-of plane $\pi$-bonding $\mathrm{K}_{\|}>\mathrm{K}_{\perp}$. From Table 5, it is observed $\mathrm{K}_{\|}>\mathrm{K}_{\perp}$, relation indicates the presence of out-of-plane $\pi$-bonding. The axial symmetry parameter $G(5.82)$ for these complexes indicates that there is no interaction between copper centers in DMF medium. The EPR X-band spectrum for the binuclear copper complex is also recorded in solid state at RT and liquid nitrogen temperature. At both temperatures the complex gives a broad signal in the low field region indication $\mathrm{g}$ spin-exchange interactions between two copper(II) ions. The two expected spin allowed EPR transition occur at 3140 and $3180 \mathrm{G}$ yielding $\mathrm{g}_{\text {iso }}$ value 2.087 copper complexes. The absence of hyperfine structure indicates that the interaction would be mainly dipolar in nature. Based on magnetic, electronic, IR and ESR spectra a binuclear trans octahedral structure is assigned (Figure 2)

Table 5. Cyclic volta metric data of BMOT metal complexes

\begin{tabular}{lccccccc}
\hline \multicolumn{1}{c}{ Complex } & \multirow{2}{*}{ Gain } & $\begin{array}{c}\text { Redox } \\
\text { couple }\end{array}$ & $\begin{array}{c}\mathrm{CV} \\
\text { cathodic } \mathrm{E}_{\mathrm{pC}}\end{array}$ & $\begin{array}{c}\mathrm{CV} \\
\text { anodic } \mathrm{E}_{\mathrm{pa}}\end{array}$ & $\Delta \mathrm{E}_{\mathrm{P}}$ & $\begin{array}{c}\mathrm{E}_{1 / 2} \\
(\mathrm{~V})\end{array}$ & $-\mathrm{i}_{\mathrm{c}} / \mathrm{i}_{\mathrm{a}}$ \\
\hline$[\mathrm{Cu}(\mathrm{BMOT})]_{2} \mathrm{Cl}_{2}$ & 0.1 & III/II & 0.44 & 0.55 & 110 & 0.495 & 0.611 \\
{$[\mathrm{Ni}(\mathrm{BMOT})]_{2} \mathrm{Cl}_{2}$} & 0.1 & III/II & -1.25 & -0.92 & 330 & -1.085 & - \\
& & II/I & -1.44 & -1.30 & 140 & -1.37 & - \\
{$\left[\mathrm{Co}(\mathrm{BMOT})\left(\mathrm{H}_{2} \mathrm{O}\right)_{2}\right]_{2} \mathrm{Cl}_{2}$} & 0.1 & IV/III & -0.53 & -0.34 & 190 & -0.435 & - \\
{$\left[\mathrm{Fe}(\mathrm{BMOT})\left(\mathrm{H}_{2} \mathrm{O}\right)_{2}\right]_{2} \mathrm{SO}_{4}$} & 0.1 & III/II & -1.27 & -0.85 & 420 & -1.06 & - \\
\hline
\end{tabular}

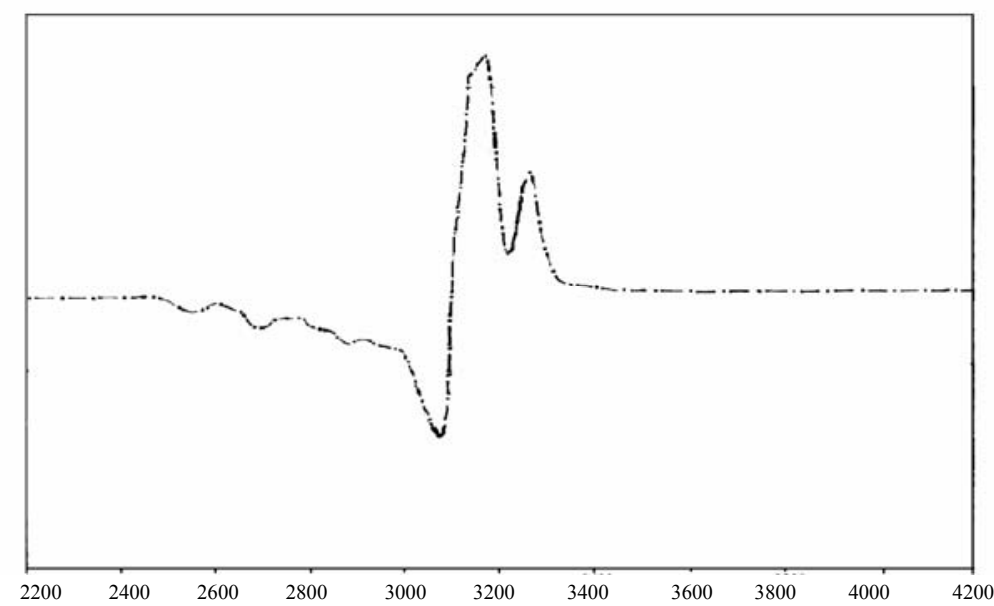

Figure 1. X-band ESR spectrum of $[\mathrm{Cu}(\mathrm{BMOT})]_{2} \mathrm{Cl}_{2}$ complex at liquid nitrogen temperature in $\mathrm{DMF}$

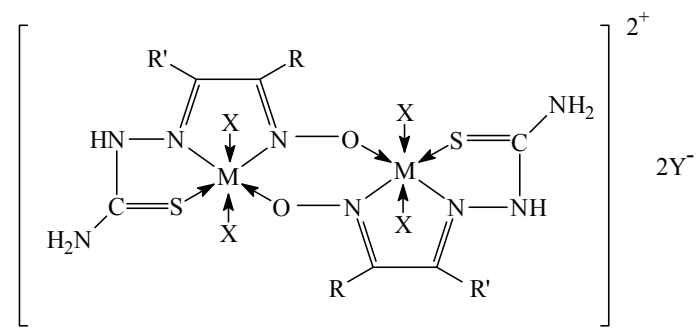

Figure 2. Structure of metal complexes where $\mathrm{M}=\mathrm{Cu}(\mathrm{II}), \mathrm{Ni}(\mathrm{II}), \mathrm{Co}(\mathrm{II})$, and $\mathrm{Fe}(\mathrm{III})$, $\mathrm{R}=\mathrm{C}_{6} \mathrm{H}_{5}, \mathrm{X}=$ Water molecule present in $\mathrm{Co}(\mathrm{II})$ and $\mathrm{Fe}(\mathrm{II})$ complexes, $\mathrm{Y}=1 / 2 \mathrm{SO}_{4}$ in $\mathrm{Fe}(\mathrm{II}) ; \mathrm{Cl}$ in $\mathrm{Cu}(\mathrm{II}), \mathrm{Ni}(\mathrm{II})$ and $\mathrm{Co}(\mathrm{II})$ complexes. 


\section{Cyclic voltammetric data}

Cyclic voltammograms (Figure 3) of the metal complexes are recorded in dimethylformamide in $\mathrm{TBAClO}_{4}$ supporting electrolyte $\mathrm{Ag} / \mathrm{AgCl}$ reference electrode. The redox behaviour of complexes has been investigated by cyclic voltammetry at a glassy carbon electrode. Table 5 gives the electrochemical data obtained at glassy carbon electrode in DMF. The cathodic peak current function values were found to be independent of the scan rate. Repeated scans, as well as different scan rates showed that dissociation does not take place in three complexes.

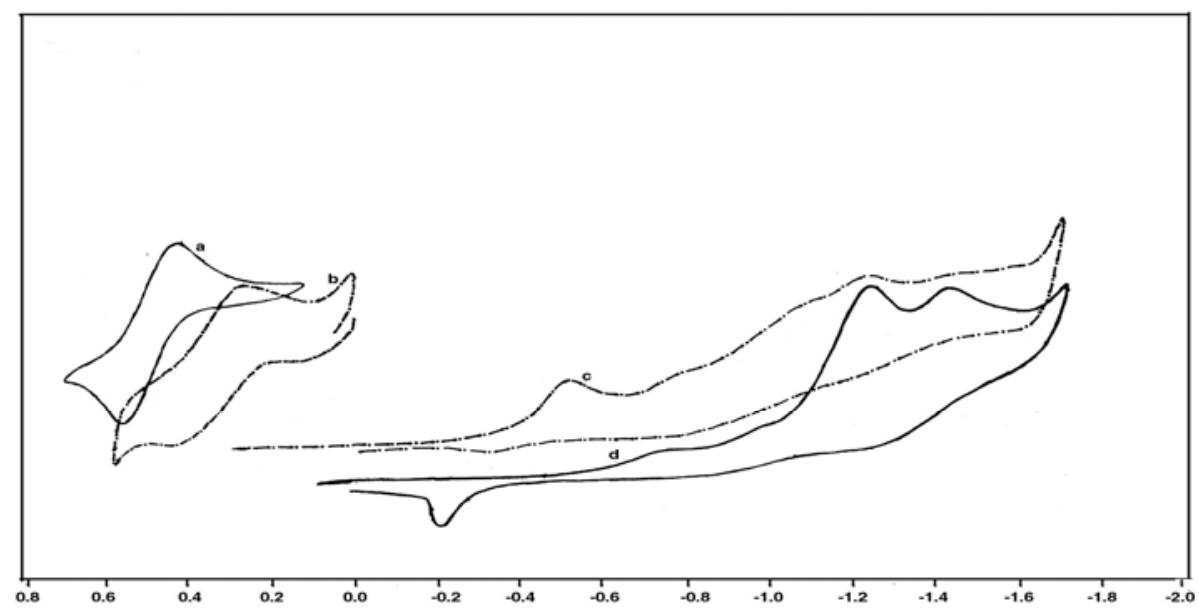

Figure 3. Cyclic voltammetric profile of (a) $[\mathrm{Cu}(\mathrm{BMOT})]_{2} \mathrm{Cl}_{2}$ (b) $\left[\mathrm{Fe}(\mathrm{BMOT})\left(\mathrm{H}_{2} \mathrm{O}\right)_{2}\right]_{2} \mathrm{SO}_{4}$ (c) $\left[\mathrm{Co}(\mathrm{BMOT})\left(\mathrm{H}_{2} \mathrm{O}\right)_{2}\right]_{2} \mathrm{Cl}_{2}$ (d) $\left[\mathrm{Ni}(\mathrm{BMOT})\left(\mathrm{H}_{2} \mathrm{O}\right)_{2}\right]_{2} \mathrm{Cl}_{2}$

The reduction peak of the $\mathrm{Fe}(\mathrm{III}) / \mathrm{Fe}$ (II) and $\mathrm{Cu}$ (III)/Cu(II) couple for these complexes is observed at the potential 0.345 and $0.495 \mathrm{Vs} \mathrm{Ag} / \mathrm{AgCl}$ for BMOT respectively ${ }^{25-27}$. The non-equivalent current intensity of cathodic and anodic peaks $\left(\mathrm{i}_{\mathrm{c}} / \mathrm{i}_{\mathrm{a}}=0.611 ; 0.653 \mathrm{~V}\right.$ at $100 \mathrm{mV} \mathrm{S}^{-1}$ ) for copper and iron. Complexes of BMOT indicate a quasi-reversible behavior. The difference $\Delta \mathrm{E}_{\mathrm{P}}=\mathrm{E}_{\mathrm{Pc}}-\mathrm{E}_{\mathrm{pa}}$ in all these complexes exceeds the Nernstion requirement $59 \mathrm{n} / \mathrm{mV}(\mathrm{n}=$ number of electrons involved in oxidation reaction) which suggests the quasireversible character of these complexes. All these complexes have large separation $(100-500 \mathrm{mV})$ between anodic and cathodic peaks indicating the quasi reversible character. The $\mathrm{E}_{1 / 2}$ values of these complexes are comparable with other complexes of nitrogen and sulphur donor ligands ${ }^{28}$.

\section{Nuclease activity of present metal complexes}

The nuclease activity on plasmid DNA can be monitored by gel agarose electrophoresis. By using the pBR322 plasmid DNA, nuclease activity was studied with BMOT and their copper(II), nickel(II), cobalt(II) and iron(II) complexes in presence and absence of hydrogen peroxide (oxidant). At micro molar concentration, the ligand exhibits no significant activity in absence and in the presence of the oxidant as shown in Figure 4. In absence of oxidant copper(II) and iron(II) complexes causes discernible DNA cleavage as shown by increase in intensity in form I (nicked) and form III (linear) with decrease in intensity in form I (super coiled) which is attributed to stepwise conversion of form I (super coiled) to form II(nicked) and to form III (linear). In presence of oxidant $\left(\mathrm{H}_{2} \mathrm{O}_{2}\right)$ all the forms of DNA is degraded by 
copper and $\mathrm{Fe}(\mathrm{BMOT})$ complex only form I (super coiled) is degraded, with increase in intensity in form II and form III respectively. Nickel complexes in the absence of oxidant show no significant nuclease activity, but in the presence of oxidant the activity is increased. The cobalt complexes of PPDOT, degraded all the three forms of DNA completely both in the presence and absence of oxidant $\left(\mathrm{H}_{2} \mathrm{O}_{2}\right)$. While in $\mathrm{Co}(\mathrm{BMOT})$ complex, an increase in activity is shown in presence of oxidant compared to absence of oxidant.

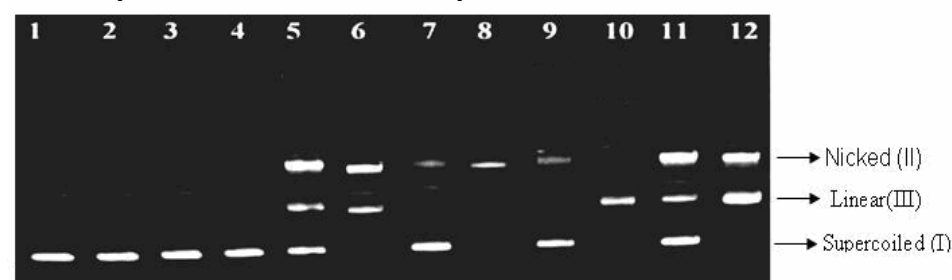

Figure 4. Agarose gel (1\%) showing the results of electrophoresis of $1 \mu \mathrm{L}$ of $(0.10 \mu \mathrm{g} / \mathrm{mL})$ pBR 322 plasmid DNA, $2 \mu \mathrm{L}$ of $0.1 \mathrm{M}$ Tris- $\mathrm{HCl}$ (pH 8.0) buffer: $250 \mu \mathrm{M}$ complex in DMF; $10 \mu \mathrm{L}$ of sterilized water and $2 \mu \mathrm{L}$ of $9.0 \mathrm{mM} \mathrm{H}_{2} \mathrm{O}_{2}$ were added, respectively, incubation at $37^{\circ} \mathrm{C}(120 \mathrm{~min})$ Lane 1: DNA (control); Lane 2: DNA $+\mathrm{H}_{2} \mathrm{O}_{2}$ (control); Lane 3 : DNA + BMOT; Lane 4: DNA + BMOT $+\mathrm{H}_{2} \mathrm{O}_{2}$; Lane 5: DNA $+\left[\mathrm{Cu}(\mathrm{BMOT})_{2}\right]$; Lane 6: DNA + $\left[\mathrm{Cu}(\mathrm{BMOT})_{2}\right]+\mathrm{H}_{2} \mathrm{O}_{2}$; Lane 7: DNA $+\left[\mathrm{Co}(\mathrm{BMOT})_{2}\right]$; Lane 8: DNA $+\left[\mathrm{Co}(\mathrm{BMOT})_{2}\right]+$ $\mathrm{H}_{2} \mathrm{O}_{2}$; Lane 9: DNA + [Ni(BMOT) $)_{2}$; Lane 10: DNA $+\left[\mathrm{Ni}(\mathrm{BMOT})_{2}\right]+\mathrm{H}_{2} \mathrm{O}_{2}$, Lane 11: DNA $+\left[\mathrm{Fe}(\mathrm{BMOT})_{2}\right] ;$ Lane 12: DNA $+\left[\mathrm{Fe}(\mathrm{BMOT})_{2}\right]+\mathrm{H}_{2} \mathrm{O}_{2}$

In overall view all the complexes showed increased nuclease activity in the presence of oxidant. The increased activity of the complexes in the presence of oxidant may be due to the formation of hydroxyl $(\mathrm{OH})$ free radical $^{29}$, which involves oxidation of the deoxyribose moiety followed by breakage of the sugar phosphate backbone. The nuclease activity of the complexes in the absence of oxidant may be due to the binding of metal ion to DNA and these metal ions can be reduced and then oxidized by dioxygen, leading to hydroxyl radical production close to the metal binding site which can damage DNA in site specific reactions or due to the reactive oxygen species (possibly singlet oxygen).

\section{References}

1. Murali S, Sastri C V and Maiya B G, Proc Indian Acad Sci (Chem Sci)., 2002, 114(4), 403-415.

2. Saenger W and C.R. Cantor, Principles of Nucleic Acid Structure, Ed., SpringerVerlag, New York, 1984, p. 253-281.

3. Wong A H J, Quigley G J, Kolpak F J, Crawford J L, Van Boom J H, Marel G V and Reich A, Nature, 1979, 282, 680-686.

4. $\quad$ Dickerson R E, Scientific American, 1983, 249(6), 87.

5. Van Dyke M M and Dervan P B, Science, 1984, 225, 1122-1127.

6. Wakelin L P G, Med Res Rev., 1986, 6, 275-340.

7. Denny W A, Anticancer Drug Design, 1989, 4, 241-263.

8. Rodriguez-Argüelles M C, Lopez-Silva E C, Sanmartin J, Pelagatti P and Zani F, $J$ Inorg Biochem., 2005, 99(11), 2231-2239

9. Costello C, Karpanen T, Lambert P A, Mistry P, Parker K J, Rathbone D L, Ren J, Wheeldon L and Worthington T, Bioorg Med Chem Lett., 2008, 18(5), 1708-1711.

10. Sebolt J S, Scavone S V , Pinter C D, Hamelehle K L, Von Hoff D D and Jackson R C, Cancer Res., 1987, 47(16), 4229-4304. 
11. Pullman B, In: Advances in Drug Research, Academic, 1989, 18, 1.

12. Kopka M L, Yoon C, Goodsell D, Pujra P and Dickerson R E, Proc Natl Acad Sci USA, 1985a, 82, 1376-1380.

13. Maniatis T, Fruisch F E and Sambrock J, Molecular Cloning, A Laboratory Manual (Cold Spring Harbor Lab. Press, Plainview, NY), pp. 149-172.

14. Yamamoto K and Kawanishi S, J Biol Chem., 1989, 264(26), 15435-15440.

15. Marfey P and Robinson E, Mutat Res., 1981, 86(2), 155-191.

16. Shinar E, Navok T and Chevon M, J Biol Chem., 1984, 23, 4158.

17. Graham D R and Sigman S D, Inorg Chem., 1984, 23, 4188-4191.

18. Hashimoto S, Yamashita R and Nakamura Y, Chem Lett., 1992, 1639-1642.

19. Dede B, Ozmen I and Karipcin F, Polyhedron, 2009, 28, 3967-3974.

20. Murali Krishna P and Hussain Reddy K, Inorg Chim Acta., 2009, 362, 4185.

21. Reichmann M E, Rice S A, Thomas C A and Doty P, J Am Chem Soc., 1954 76, 3047.

22. Vogel A I, A Text book of Practical Organic Chemistry, 1978, $4^{\text {th }}$ Edn., Longmans, Green and Co. Ltd., London, P. 811.

23. Tian Y, Duan C, Zheo C, You X, T C W and Zhang Z, Inorg Chem., 1997, 36, 1247.

24. Raman N, Kulandaiswamy A and Jayasubramania K, Indian J Chem., 2002, 41A, 942-949.

25. Mamdoush S. Masoud, Saedq A. Abou Elenein and Hesham M. Kamel, Indian J Chem., 2002, 41(2)A, 297-303.

26. Hussain Reddy K, Sambasiva Reddy P and Ravindra Babu P, J Inorg Biochem., 1999, 77, 169-176.

27. Kissinger P T and Heineman W R, J Chem Edu., 1983, 60(9), 703-706.

28. Mandal S and Bharadwaj P K, Polyhedron, 1992, 11, 1037.

29. Shukal R, Mandal S and Bharadwaj P K, Polyhedron, 1993, 12, 83. 


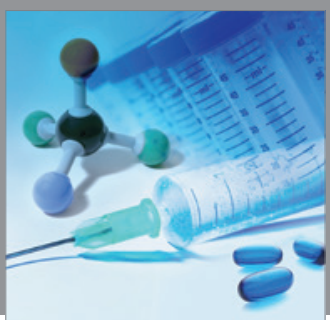

International Journal of

Medicinal Chemistry

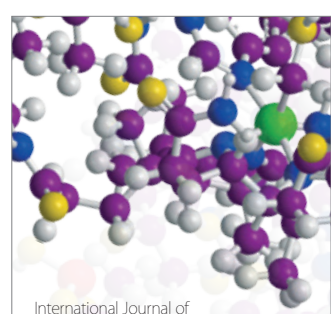

Carbohydrate Chemistry

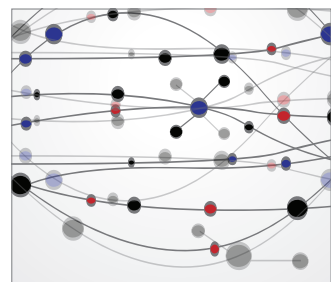

The Scientific World Journal
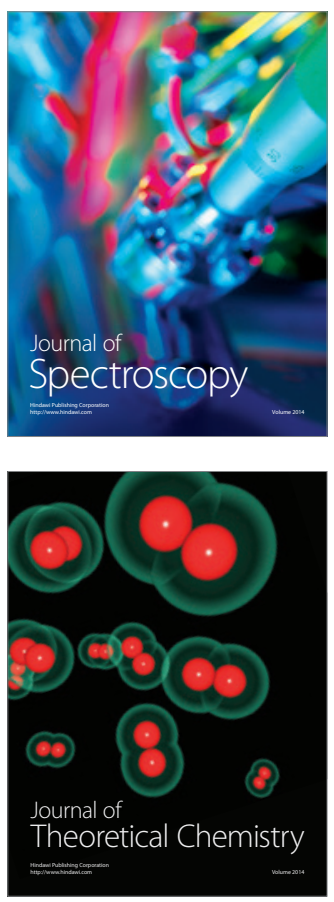
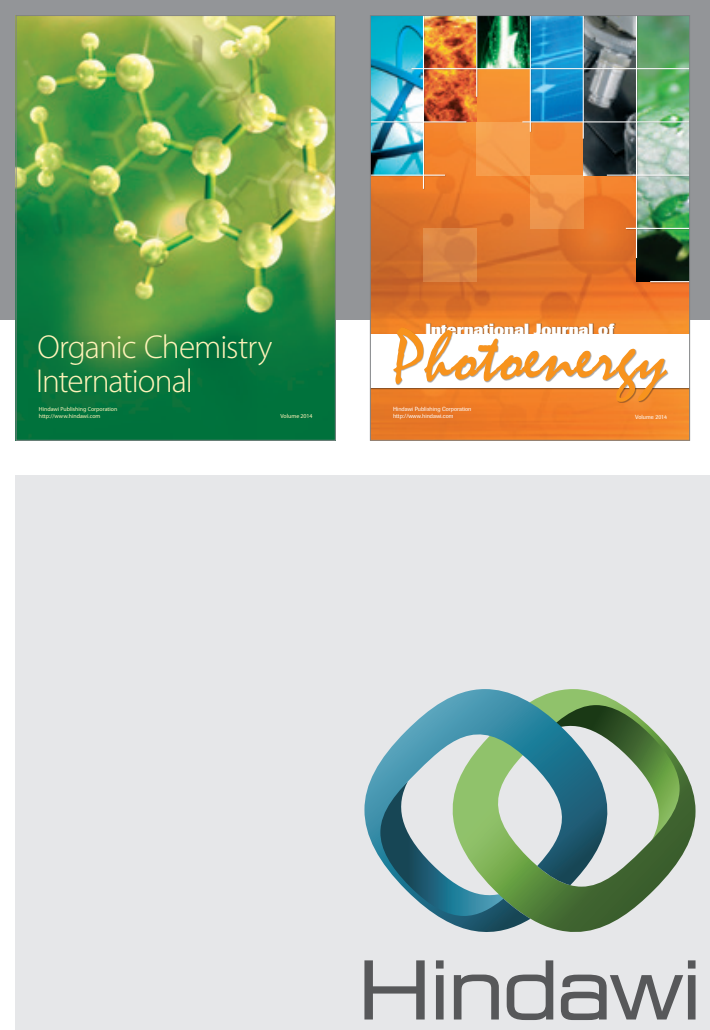

Submit your manuscripts at

http://www.hindawi.com
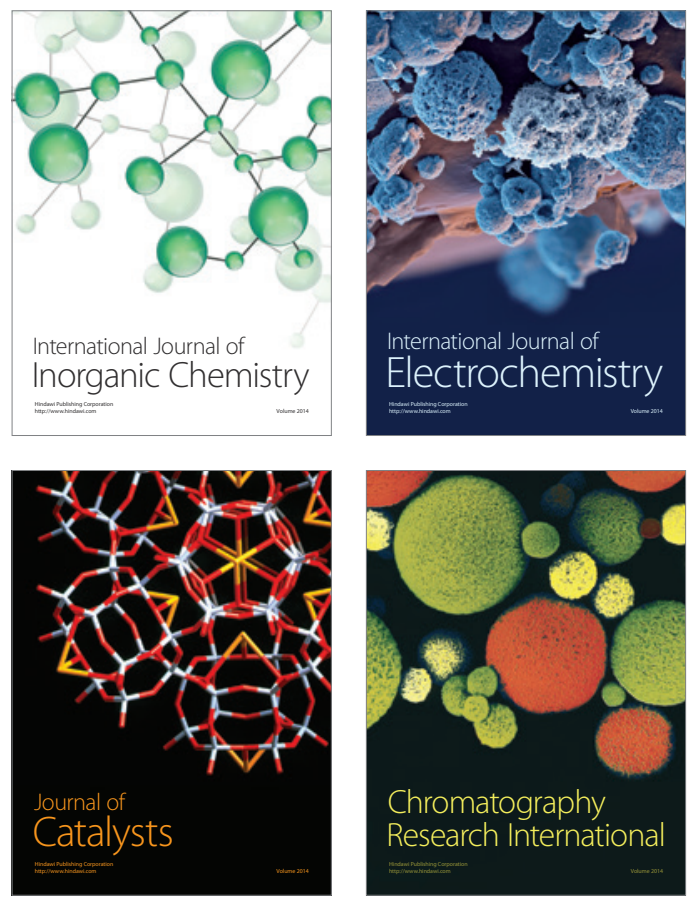
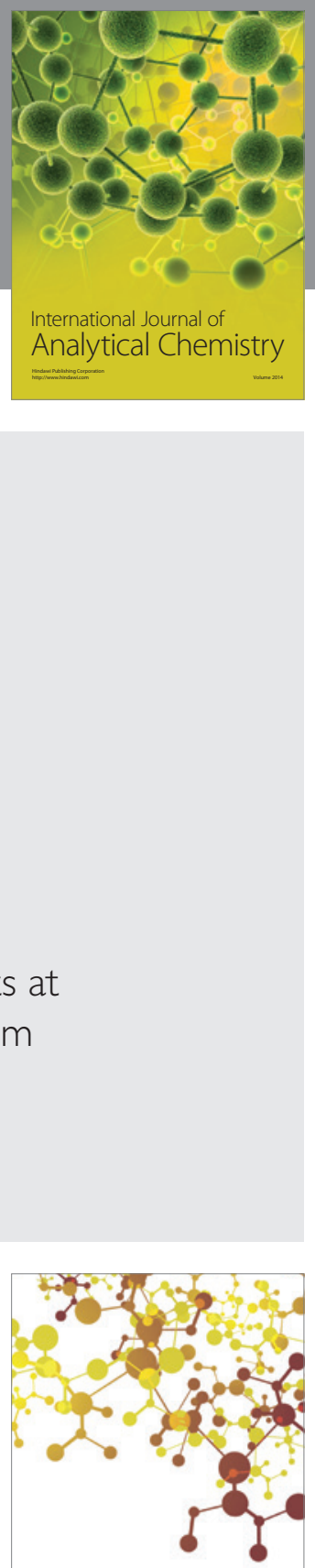

Journal of

Applied Chemistry
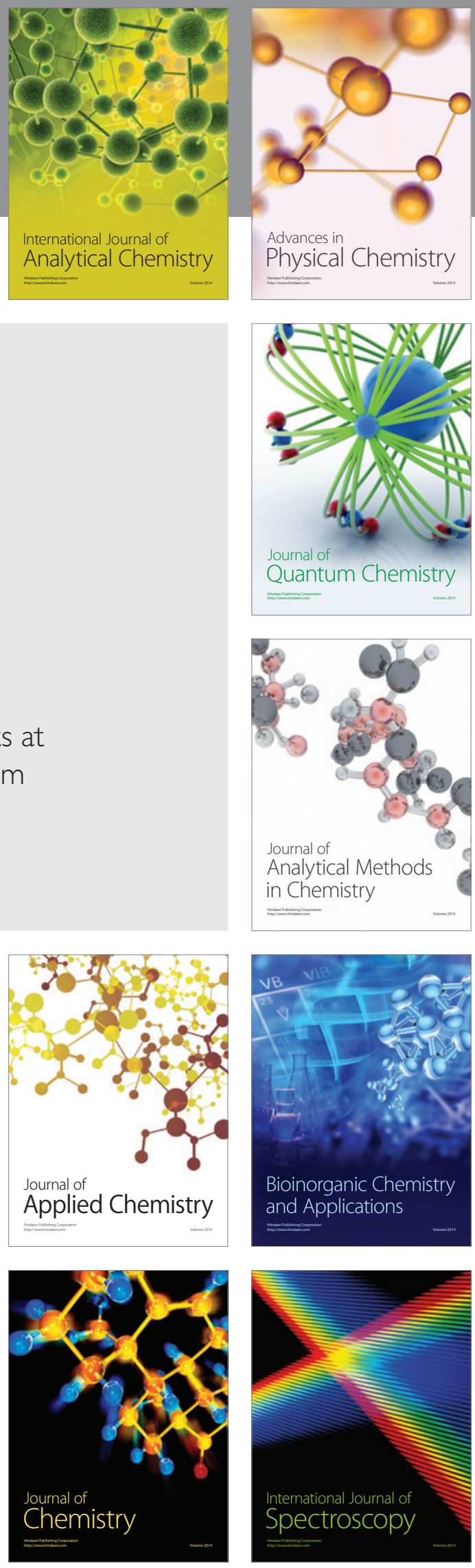